Max-Planck-Institut für demografische Forschung

Max Planck Institute for Demographic Research

Konrad-Zuse-Strasse $1 \cdot$ D-18057 Rostock · GERMANY

Tel +49 (0) 3812081 - 0; Fax +49 (0) 3812081 - 202;

http://www.demogr.mpg.de

MPIDR WORKING PAPER WP 2008-004

JANUARY 2008 (REVISED FEBRUARY 2008)

\title{
Economic insecurity and cohabitation strategies in Italy
}

Christin Schröder (schroeder@demogr.mpg.de)

This working paper has been approved for release by: Laura Bernardi (bernardi@demogr.mpg.de) Head of the Independent Research Group on The Culture of Reproduction.

(C) Copyright is held by the authors.

Working papers of the Max Planck Institute for Demographic Research receive only limited review. Views or opinions expressed in working papers are attributable to the authors and do not necessarily reflect those of the Institute. 


\title{
Economic Insecurity and Cohabitation Strategies in Italy
}

\author{
Christin Schröder
}

\begin{abstract}
A particular aspect of demographic behavior among young people in Italy is postponement of entering first union. High youth unemployment, a tense housing situation, and a passive welfare state are currently creating a precarious economic situation, in which most young adults are unable to choose cohabitation. Thus, not surprisingly, previous studies found evidence that in Italy cohabitation was only a choice for people who were economically independent. Also of interest is that the percentage of informal unions varies to a considerable extent across Italy, showing higher proportions of cohabitation in the more prosperous regions of the North, unlike the South, where informal unions are much less prevalent and the economic system is affected by mismanagement, unemployment, and the informal economy. This suggests an interrelationship between the diffusion of cohabitation and the regional economic situation.

In this qualitative study we are particularly interested in the question of how job insecurity affects cohabitation - or more precisely: How are job insecurity and resulting economic shortages related to the hesitant spread of cohabitation in Italy? For our analysis we investigated two different regional settings: Bologna in the North and Cagliari (Sardinia) in the South.

Our findings show that, when compared to their counterparts in Cagliari, couples in Bologna benefited from higher opportunities to access at least temporary job contracts. Benefiting also from the availability of parental support during cohabitation, the Bologna couples faced fewer obstacles when deciding on an informal union. In Cagliari, couples were strongly affected by unstable employment conditions; further, the lack of parental approval of cohabitation often led to decreasing economic support, thereby making cohabitation an expensive choice.
\end{abstract}




\section{INTRODUCTION}

Italy has attracted attention for its particular patterns of demographic behavior. The country has experienced both a dramatic postponement of events related to the transition to adulthood, such as leaving the parental home (Billari 2004) and "lowest-low" levels of fertility (Kohler et al. 2002). One of the most puzzling demographic characteristics of the country has been the slow spread of alternative living arrangements. In contrast to their European counterparts, young adults in Italy decide less often to live alone or to cohabit (Kiernan 1999, 2004). Kiernan (2004) found evidence that in 2001 only $8 \%$ of Italian adults aged 25 to 34 were living in an informal union, whereas cohabitation rates were much higher in Scandinavia and western Europe (e.g., Sweden 39\%, France 31\%, Netherlands 22\%). Not only were there low levels of informal union, but also the diffusion of such unions across Italy varied considerably. Cohabitation tended to be more widespread among the northern and central regions of Italy and less common in the South and the Islands (ISTAT 2001). However, more recent data indicate strong increases in cohabitation among the younger generations: One out of four women born between 1970 and 1974 and living in northern or central Italy started their first union with cohabitation. Though rates are rising in the South as well, they reach lower levels (Gruppo di Coordinamento per la Demografia 2007, based on FSS 2003).

In general, it is argued that economic dependence on the family, the rigid structure of the housing market and high youth unemployment rates culminate in a striking postponement in the transition to adulthood (Ferrera 1996; Rossi 1997; Reher 1998; Aassve et al. 2000; Holdsworth and Irazoqui Solda 2002). It has been assumed that family ties, which in the Mediterranean area are particularly strong, further hamper the formation of informal unions (Rosina and Fraboni 2004; Schröder 2006, 2007; Di Giulio and Rosina 2007). So, not surprisingly, previous studies found that informal unions are usually found among people who are economically relatively independent from their families of origin (Grillo and Pinnelli 1999; Schizzerotto and Lucchini 2002). This suggests that economic independence is one major precondition for cohabitation. However, given the difficult labor market situation in Italy, young adults face significant barriers to reaching 
financial independence. So, we are particularly interested in the question of how job insecurity affects cohabitation.

In general, job insecurity refers to the perceived probability of losing one's employment (Becker et al. 2005). Bernardi et al. (2007) actually emphasize the difference between insecurity and uncertainty: Whereas insecurity refers to an uncertain labor market and resulting economic insecurity (with reference to Mills and Blossfeld 2005), uncertainty describes the uncertain biographical future as a major consequence of job instability (with reference to Hurrelmann 2003). In our analysis, we are primarily interested in the former, that is, the insecure labor market and the effect of resulting economic shortages on informal union formation in Italy.

More precisely, our research question is the following: How is job insecurity perceived among young adults and how does this subjective perception relate to individual choices of cohabitation and marriage, possibly accounting for the hesitant spread of informal unions in the country? In order to gain more insight into this question, we employ qualitative research methods, which allow for a detailed investigation of subjective perceptions and individual behavior. Furthermore, our research design enables us to analyze the influence of both partners' economic situations with regard to informal union formation. As most previous studies concentrated exclusively on either the male's or the female's employment and financial situation, our approach contributes to a more comprehensive understanding of the question at hand (Smock and Manning 1997).

Within the scope of our study, we conducted 56 qualitative interviews in two regional settings. Half of the interviews were arranged in Bologna, a city that witnesses relatively low marriage rates (3.5 marriages per 1,000 inhabitants in 2005) and the highest diffusion of informal unions in Italy (7.6\% in 2001). The other half were conducted in Cagliari, at the southern tip of Sardinia, where marriage rates are higher (4.1 marriages per 1,000 inhabitants in 2005) and cohabitation is much less diffused (3.2\% in 2001). In addition, the cities are characterized by different labor market conditions. Although unemployment, especially among youth, tends to be high in the whole of Italy, Sardinia suffers from extraordinarily severe employment problems. In 
2001 , about $50 \%$ of the young adult population were looking for a job (ISTAT 2001; ISTAT 2006).

In the next section of this paper we focus on the economic conditions to which young Italian adults are exposed. We refer to the peculiarities of the Italian labor and housing market and related problems confronting young adults. Next we present the theoretical framework from which we derive our hypotheses. We then describe the data and method used to investigate the relationship between labor market and economic insecurity and cohabitation among young adults. In the final section we present the results and a concluding discussion.

\section{ECONOMIC CONDITIONS OF YOUNG ADULTS IN ITALY}

The economic situation of young Italian adults is strongly shaped by two components: the Italian labor market and the housing market. Within the Italian labor market young adults face huge difficulties finding a job. Over the last two decades several developments have increased insecurity among most Italians: a stagnant economy, the delocalization of medium-sized and small firms, and the increasing diffusion of precarious employment relations (Pisati and Schizzerotto 2003). One can identify two groups of employees that stand in direct contrast to each other: on the one hand, the older cohorts who still profit from the strong employment protection guarantees of the 1960s and 1970s, and on the other hand, the younger cohorts who are more prone to unemployment and unstable job situations (Bernardi and Nazio 2005) - a development that has been described as the "gerontologization" of work (Sgritta 2002). Dietrich (2002) emphasizes that in nearly all European countries the probability of entering a job creation program increases with duration of unemployment, but this is not the case in Italy. On the contrary, Italy is characterized by a weak connection between the educational system and the labor market, which leads to a long and problematic school-to-work transition (Bernardi and Nazio 2005). In 2005, 36.8\% of Italian people aged 15-19 were looking for a job; $21.1 \%$ of adults aged $20-24$ and $13.1 \%$ of the $25-29$ age group were similarly situated (ISTAT 2006). Taking a closer look at the distribution of unemployment by age group and gender, we discover that the disadvantaged are mainly women 
and young adults in general (see Figure 1). In addition, the Italian welfare state protects only employed individuals and ignores those who are not yet successful in entering the labor market (Ferrera 1996).

Figure 1: Percentage of unemployment, by age group and gender, 2005.

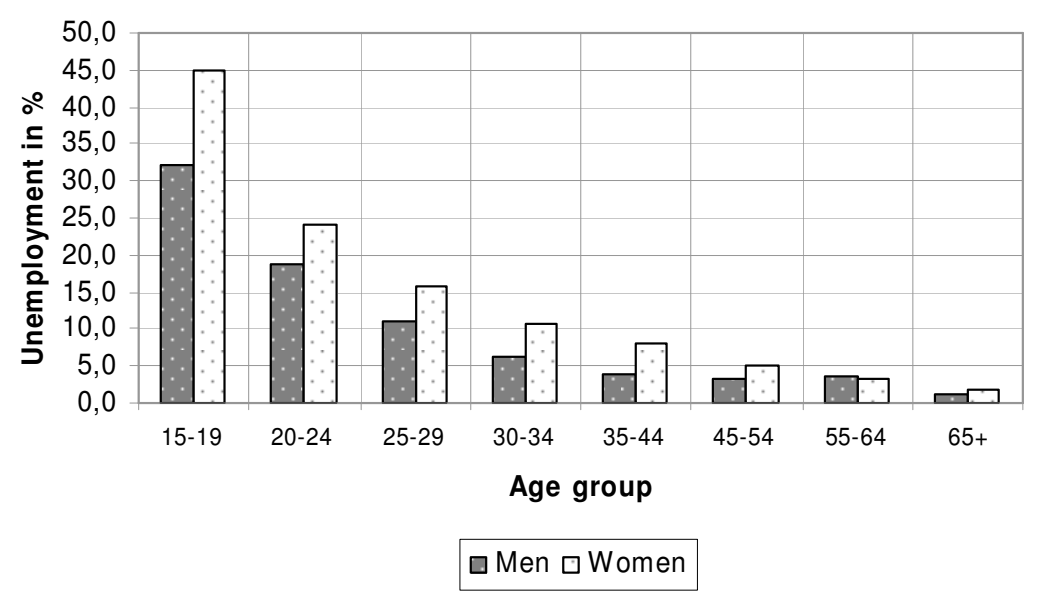

Source: ISTAT, Annuario Statistico Italiano 2006.

In their study on young Spaniards who, compared to young adults in Italy, live in a similar economic situation, Simó Noguera et al. (2005) analyze the effect of globalization on the transition to adulthood. The authors come to the conclusion that the risks and uncertainties associated with globalization, in particular those regarding occupation, "are not equally spread across all workers but have channeled towards those age groups which are precisely at the life cycle stage of family formation" (Simó Noguera et al. 2005: 380). Bernardi and Nazio (2005) argued as well that "when compared with their peers in other nations - possibly with the exception of Spain - Italian youngsters seem to be particularly exposed to the new forms of insecurity brought about by the globalization process" (Bernardi and Nazio 2005: 351). Furthermore, Dolado et al. (2000) observed a process of crowding-out in which higher educated youth replaced less educated people in their traditional positions. In the absence of alternatives, young adults opt increasingly to stay longer in education. It has become rather common to "accumulate" one university degree after the other. However, unemployment and job insecurity among university graduates is high as well (ISTAT 2006). Meanwhile, new types of employment contracts are increasingly prevalent: the so-called coordinated continuous collaborations (or "co.co.co"), contracts 
for a project ("co.pro") or freelance activities where people work as consultant or collaborator without any protection or security regarding the continuity of their work. Even if they are formally independent, these people occupy de facto subordinate positions (Bernardi and Nazio 2005; Fondazione Giacomo Brodolini 2007).

As to the housing market, Italy is characterized by a tight market situation, mainly due to the prevalence of housing property and the lack of effective housing programs to support people with lower incomes in finding an adequate dwelling to rent (Brütting 1997). Holdsworth and Irazoqui Solda (2002) argue that the prevalence of housing property is actually one major reason for the low diffusion of alternative living arrangements in southern Europe. According to their argument, in the Netherlands $92 \%$ of single and $81 \%$ of cohabiting entrants rent an apartment. The rigid structure of the Mediterranean housing market, however, hinders a similar pattern. In Spain, market analysts identify "young people from more privileged backgrounds with greater accumulation of human capital" (Holdworth and Irazoqui Solda 2002: 15), who can afford not to buy and thus have greater flexibility to decide to enter cohabitation.

At present, in a society where - due to an insecure labor market and dramatically high renting costs - young adults can hardly afford to live in economic independence, the importance of the family as a safety net increases significantly. This is especially true for Italy, where the state refrains from supporting young unemployed adults. It is not surprising then that these adults tend to depend on their parents, even at ages at which their European counterparts have generally managed to achieve an independent adult lifestyle. Analyzing the transition out of the parental home among cohorts born around the 1960s, Billari and colleagues (2001) found that it is Italian men who leave the latest (on average at age 26.7 as compared to age 20.2 in Sweden, 21.5 in France, and 22.5 in The Netherlands). Italian adults actually tend to leave home so late that Billari (2004) refers to this group as the "latest-late." However, the consequences of this process are dramatic: The postponement of leaving home results in a delayed entry into union and transition to parenthood with severe effects on fertility rates. Kohler et al. (2002) argue that there is a direct link between 
youth unemployment and demographic events in young adulthood. Studies have found evidence that in Italy successful entry into the labor market tends to accelerate household and union formation (Billari et al. 2000). Thus, it seems that young adults tend to postpone the transition to both formal and informal unions until they have reached a certain level of economic stability.

\section{THEORETICAL FRAMEWORK AND HYPOTHESES}

Much past research, both theoretical and analytical, has been done on the interrelationship between economic factors and the transition to marriage. It has been argued that men with higher earnings and more secure jobs are more likely to marry, as they enjoy greater attraction in the marriage market (Becker 1981). In the same vein, Oppenheimer (1997) suggests a similar mechanism among women: Compared to unemployed or low-income women, those with good jobs show a stronger tendency to decide on marriage. In contrast, White and Rogers (2000) (with reference to Cherlin 1992) point to the "independence effect," which assumes that higher-income women feel less pressure to marry for economic reasons and thus may instead decide on an informal union rather than marriage. Notwithstanding, empirical evidence on this effect is weak.

Compared to the high number of theoretical and analytical papers that link economic conditions and marriage, only a few studies address the interrelationship between economic factors and the transition to cohabitation. In addition, hardly any research refers directly to the peculiar situation in Italy.

In the following, we shall present a number of considerations that seem to be most useful for the analysis of the impact of labor market and economic insecurity on informal union formation in Italy.

\section{(1) Compatibility of Insecurity with Cohabitation}

Many scholars have argued that informal unions - in contrast to marriages are more compatible with the new demands of today's labor market, such as mobility, flexibility, and the resulting insecurity. This applies to both 
Western countries in general (Oppenheimer 1988; Mulder and Manting 1994) as well as Italy in particular (Rosina and Billari 2003). Lewis et al. (1999), who analyzed young Europeans' orientations to family and work, assume that "in the context of longer periods spent in education or training and the growing insecurity of work, the participants appear to live in an extended present, where current work-life priorities remain sharply in focus. As a consequence [...] it is difficult for them to plan for future work and family arrangements" (Lewis et al. 1999: 83). In line with this argument, cohabitation appears to be an adequate alternative to marriage, since it allows for living together without taking on long-term responsibilities that are usually associated with an enduring union such as marriage. Thus, an increase in insecure jobs would, in the long run, promote the diffusion of informal unions. We are particularly interested to see whether, at the individual level, this argument holds for Italy as well. However, we suspect that the economic level provided by an insecure job position might be too low and unstable to afford living on one's own - especially in cases where both partners are affected by such unfavorable employment conditions. We further assume that the higher level of unemployment limits the opportunity of couples in Cagliari to combine job insecurity and cohabitation.

\section{(2) Availability of Earnings}

As noted earlier in this paper, earnings, i.e., economic independence, constitute an important precondition for entering either cohabitation or marriage (Billari et al. 2000; Grillo and Pinnelli 1999; Schizzerotto and Lucchini 2002). However, the question to be addressed here is this: In the Italian context, which one of the two choices - cohabitation or marriage - is more expensive for young adults? These costs refer to both direct financial investment and social cost. The latter might actually represent economic costs as well, for instance, in cases where parents withdraw from supporting their children economically as, in their perception, their offspring behave in a socially unacceptable way. In the following, we shall discuss the ways in which the choice of marriage or cohabitation might become expensive:

\section{(2a) Marriage as an Expensive Choice}

Based on assumptions about Western countries in general and the United States in particular, Oppenheimer (1994) argues that the transition to 
marriage involves a much higher cost than the choice of cohabitation. She assumes that social norms dictate a certain standard of living once a couple decides to marry. Clarkberg (1999) believes that the same social norms are not in force when it comes to informal union formation: "Because cohabitation - a relatively uninstitutionalized form of union - carries few prescriptions for an "appropriate" lifestyle, the failure to meet some "suitable" level of income may not be a barrier to forming a nonmarital union” (Clarkberg 1999: 951). As a consequence, couples facing strong economic insecurity might be inclined to cohabit rather than marry. However, the extent to which couples may decide against marriage and in favor of cohabitation depends to a huge extent on societal norms, as expressed by Wilson (1996): "The weaker the norms against premarital sex, out-of-wedlock pregnancy, and nonmarital parenthood, the more that economic considerations affect decisions to marry" (Wilson 1996: 97). Based on these considerations, couples living in poorer economic conditions would rather opt for cohabitation than for marriage - provided that at least a certain level of acceptance of informal unions prevails. We actually doubt that this acceptance has yet won recognition in the whole of Italy. Instead, we assume that it is mainly couples in metropolitan areas who have profited from a higher level of acceptance. Thus, couples in Bologna might be particularly prone to favor cohabitation over marriage for economic reasons.

\section{(2b) Cohabitation as an Expensive Choice}

Recent research that focuses on the particular context of Italy suggests, in contrast, that for young adults the transition to marriage might be more advantageous than the choice of cohabitation (Di Giulio and Rosina 2007; Schröder 2007). As the Italian welfare state does not provide support for young adults, the family becomes more important as provider of social security. It has been found that parents are more likely to support their adult offspring when they decide for conventional and social accepted living arrangements such as marriage (Rosina and Fraboni 2004). The choice for informal unions, by contrast, might be more cost-intensive as parents tend to withdraw from supporting their adult children (Di Giulio and Rosina 2007; Schröder 2007). Under these conditions, labor market insecurity might promote entry into marriage rather than transition to cohabitation. 
In our study, we investigate how labor market and economic insecurity affect couples who actually decided to enter cohabitation. Further, we are interested in analyzing how these unions deal with economic insecurity and how their financial conditions influence the transition to a potential subsequent marriage. For that reason, our study concentrates both on women who entered cohabitation as a first union and those who chose marriage afterwards. Moreover, Smock and Manning (1997) emphasize, earlier studies that include economic considerations take merely the men's or the women's earnings into account. We want to overcome these limitations by considering the labor market and economic situation of both partners. Empirical studies have found that compared to women's earnings, the income of men are in fact much more important when it comes to family formation (White and Rogers 2000). For Italy, we expect the same mechanism to apply, as the Italian welfare state gives women few options to combine work and family responsibilities (Saraceno 1994; Barbagli and Saraceno 1997). In light of these conditions, the male role of main breadwinner continues to be highly important.

Furthermore, previous studies address only Italy as a whole, ignoring the high degree of regional heterogeneity across the country. Young adults might perceive both economic insecurity and the meaning of union formation choices differently from one regional setting to another. The need for an investigation that takes into account the subjective meaning that individuals attach to insecurity has been emphasized by Bernardi et al. (2007). In their qualitative study on Germany the authors found, for instance, that expectations of adults and priorities within the life course were responsible for different patterns in the transition to parenthood in the eastern and western part of the country (Bernardi et al. 2007). The same might be true for Italy. So, we are particularly interested in the way young adults in Bologna and Cagliari perceive their economic situation and the way in which they combine financial insecurity with informal union formation. 


\section{DATA AND METHOD}

For our study we employed qualitative research methods. These methods permitted an extensive consideration of the phenomenon at hand and allowed for deep insights into the questions of interest.

As mentioned earlier, we selected two different regional settings. First, we chose Bologna, the capital city of the northern Italian region of EmiliaRomagna. Today, this region shows the highest diffusion of informal unions in the country. In addition, Emilia-Romagna has a labor market that, compared to the whole of Italy, is rather favorable towards young adults. In 2001, youth unemployment stood at 12.4\% (see Figure 2). Our second location was Cagliari, the capital city of the island of Sardinia. Cohabitation rates are much lower there, and young adults are confronted with extraordinarily high unemployment. In 2001, about $53.8 \%$ of young people in Sardinia were looking for employment (ISTAT 2001). As a result, Sardinia witnesses high rates of emigration. Data show that both the Islands and the South of Italy have negative net migration rates, whereas northern and central Italian areas show positive rates (Gruppo di Coordinamento per la Demografia 2007). High numbers of (young) adults actually leave the Islands and the South to search for occupations in the North (Bubbico 2005).

Figure 2: Percentage of youth unemployment (age 15 - 24), by region, 2001.1

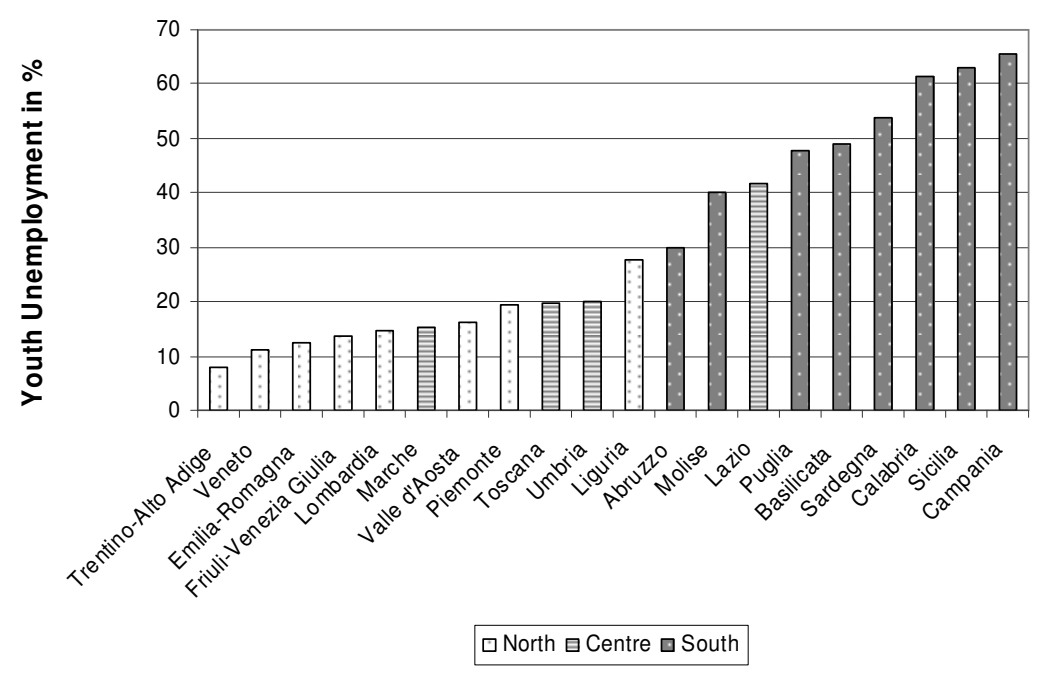

Source: ISTAT, Census 2001.

\footnotetext{
${ }^{1}$ The data for southern Italy especially might be biased by the fact that individuals who are working in the informal economy, are probably inclined to report unemployment instead of illegal work.
} 
Between May 2005 and May 2006, we conducted 56 semi-structured indepth interviews (28 interviews in each of the two cities) with cohabiting women, women who married after previous cohabitation, and women with and without children. The Bologna interviewees were identified through register data and were contacted first by phone and then by mail. Furthermore, we used the snowball method (Goodman 1961) to complete our sample. For Cagliari, we used the snowball method only and started with contact persons at social and information services. We decided for this (additional) sampling procedure as cohabiters are relatively rare in Italy and not directly listed at the registry offices. ${ }^{2}$ Despite the fact that the snowball method allowed us to collect information from a relatively hidden group of people, we are aware that this approach has some limitations. As Erickson (1979) emphasized, the snowball method produces biases in several ways: both the initial sample and additional individuals are not found randomly; participants usually include those individuals willing to cooperate and exclude those who instead withdraw from participation; further biases arise from the fact that interviewees might tend to "protect" friends by not referring to them and by the fact that respondents with a large network of friends will be oversampled, while more isolated persons will be excluded. We expect that our Cagliari sample is biased by the fact that we started our search for interviewees at social and information services, as some of them engaged especially in women's issues and referred to potential respondents who had dealt already with certain problems such as the status of women in the society. As a consequence, these women were much more informed and sensitive to certain issues (for example, gender relations within the couple) as this seemed to be the case in Bologna.

Initially, we intended to interview women aged between 25 and 40, and most women in our final sample were actually from this age group. In the final data set for Bologna we have information on 17 cohabiting women (two of them mothers) and eleven married women (three of them childless). Most of the women were born and raised in Bologna; others moved to the city because of their studies. At the time of the interview they had already been

\footnotetext{
${ }^{2}$ Although several municipalities (Turin being a forerunner) started to allow couples to register an informal union, up to 2005 in Bologna only five couples did so. In both Bologna and Cagliari, we had no access to that category of data.
} 
living there for many years (see Table 1 for more detailed information). In Cagliari we interviewed 16 cohabiting women (five of them mothers) and eleven married women (six of them childless). Another interviewee was single and intended to enter cohabitation within the next six months. Again, most of the women were native to Cagliari, while the others came from elsewhere in Sardinia and only three were from the Italian mainland.

Though we did not sample for education, most of the interviewees in Bologna and Cagliari had completed university education. This was not surprising, since several studies have found evidence that in Italy higher educated adults are especially prone to enter cohabitation (Sabbadini 1997; Rosina and Fraboni 2004). Nonetheless, recent data show that university graduates face high risks of unemployment too (ISTAT 2006). As to employment, there were many white-collar workers in both samples, including several working in the public sector. In Bologna, two interviewees were still students. And both city samples included women who came from the medical, teaching, or photography professions.

Table 1: Description of the Bologna and Cagliari Samples

\begin{tabular}{|c|c|c|c|}
\hline & & Bologna & Cagliari \\
\hline \multirow{4}{*}{ Marital status } & Cohabiting and childless & 15 & 11 (+ 1 Single) \\
\hline & Cohabiting and mother & 2 & 5 \\
\hline & Married and childless & 3 & 6 \\
\hline & Married and mother & 8 & 5 \\
\hline \multirow{4}{*}{ Region of birth } & Same city & 15 & 15 \\
\hline & Same region & 6 & 10 \\
\hline & North/Center & 3 & 2 \\
\hline & South & 4 & 1 \\
\hline \multirow{3}{*}{ Educational level } & Lower Secondary & 2 & 1 \\
\hline & Higher Secondary & 4 & 5 \\
\hline & University Degree & 22 & 22 \\
\hline
\end{tabular}

As we interviewed both women who were cohabiting at the time of the interview and those who had experienced cohabitation before their wedding, our data allowed for the investigation of economic insecurity when women made the transition from an informal to a formal union. 
The interview guidelines covered several major topics, such as the decision to cohabit (or marry), information on labor histories, economic conditions, family support, and so forth. Following the interview, the respondents answered a short questionnaire on their socio-demographic characteristics. Most interviews were about 50 to 60 minutes long. After conducting and recording the interviews, all audio tapes were transcribed. This enabled us to go back to the data several times. In a further step we coded the material. The coding and categorizing of the interviews was inspired by grounded theory (Glaser and Strauss 1967). Grounded theory employs three steps of coding and categorizing to analyze qualitative data: open, axial, and selective coding. Open coding refers to labeling of data sentence-by-sentence or paragraph-by-paragraph. Next, labels are combined to categories and axes between them are identified. During axial coding the number of codes is reduced, and the different axes between the phenomenon and its context, intervening factors and consequences are drawn up (Glaser and Strauss 1967; Corbin and Strauss 1990). Finally, selective coding aims at "elaborat[ing] the core category around which the other developed categories can be grouped and by which they are integrated" (Flick 2002: 182). The end result of qualitative research is the generation of theory.

In the results section, following, we present separate findings for each regional context: for Bologna first, then for Cagliari. The final section of the paper provides a comparison of the two settings and a brief discussion.

\section{RESULTS}

\section{1 "Economic Insecurity at the Initial Stage of Professional Life" in Bologna}

Following the procedure of Glaser and Strauss (1967) we developed a coding paradigm that gives an overview of the conditions, intervening factors, and consequences related to the phenomenon at hand and the respective categories. This coding paradigm is displayed in Figure 3. In the following we shall describe the content of each category involved. 
As described earlier, young adults in Italy generally face severe difficulties in finding an adequate employment position. The women we interviewed in Bologna experienced the same situation; they actually experienced "economic insecurity at the initial stage of their professional life." Even though most of our interviewees had achieved high or very high levels of education, they reported instability and uncertainty in their career. Primarily, women faced difficulties finding a position that corresponded to their studies. Especially at the beginning of their professional life, interviewees had to rely on occasional jobs and unpaid internships. Sofia, aged 39 and cohabiting, finished her studies at age 30. She stressed the variety of jobs she had to take after graduating from university:

"I started by standing in for a teacher giving lessons at primary school. Apart from that, I did various things. I was an actor for a certain period of time. Or I worked in summer as kitchen help in restaurants. For several years I worked with teenagers at risk."a

Among this range of jobs there was only one occupation that related to her training. Other women had similar experiences to Sofia's: they often worked as waitress, secretarial help, conference hostess or did some private teaching. In light of their educational degrees, interviewees pointed out that the lack of employment and the instability of available jobs was "dequalifying” them in terms of their professional development. Several women held temporary jobs or project contracts from several months to one or two years. As these jobs ended after a short period of time, they offered a low level of social security. Federica, aged 33 and married, reported, for instance, that her contract was not renewed when she became pregnant with her first child. Despite the high degree of social insecurity, several interviewees managed to reach relatively secure positions - mainly in the public sector. These jobs were generally characterized by open-ended or at least longerlasting contracts. In addition, women benefited from flexible working hours in these jobs - an important advantage when anticipating childbirth. Still, it took these women several years to get hired for such positions that allowed for "economic stability later in life." 
Men in Bologna, in contrast, seemed to face much less of a problem. Despite the fact that fewer males held university degrees than their female partners, ${ }^{3}$ they often had managerial positions.

Figure 3: Coding Paradigm for the Bologna Interviews

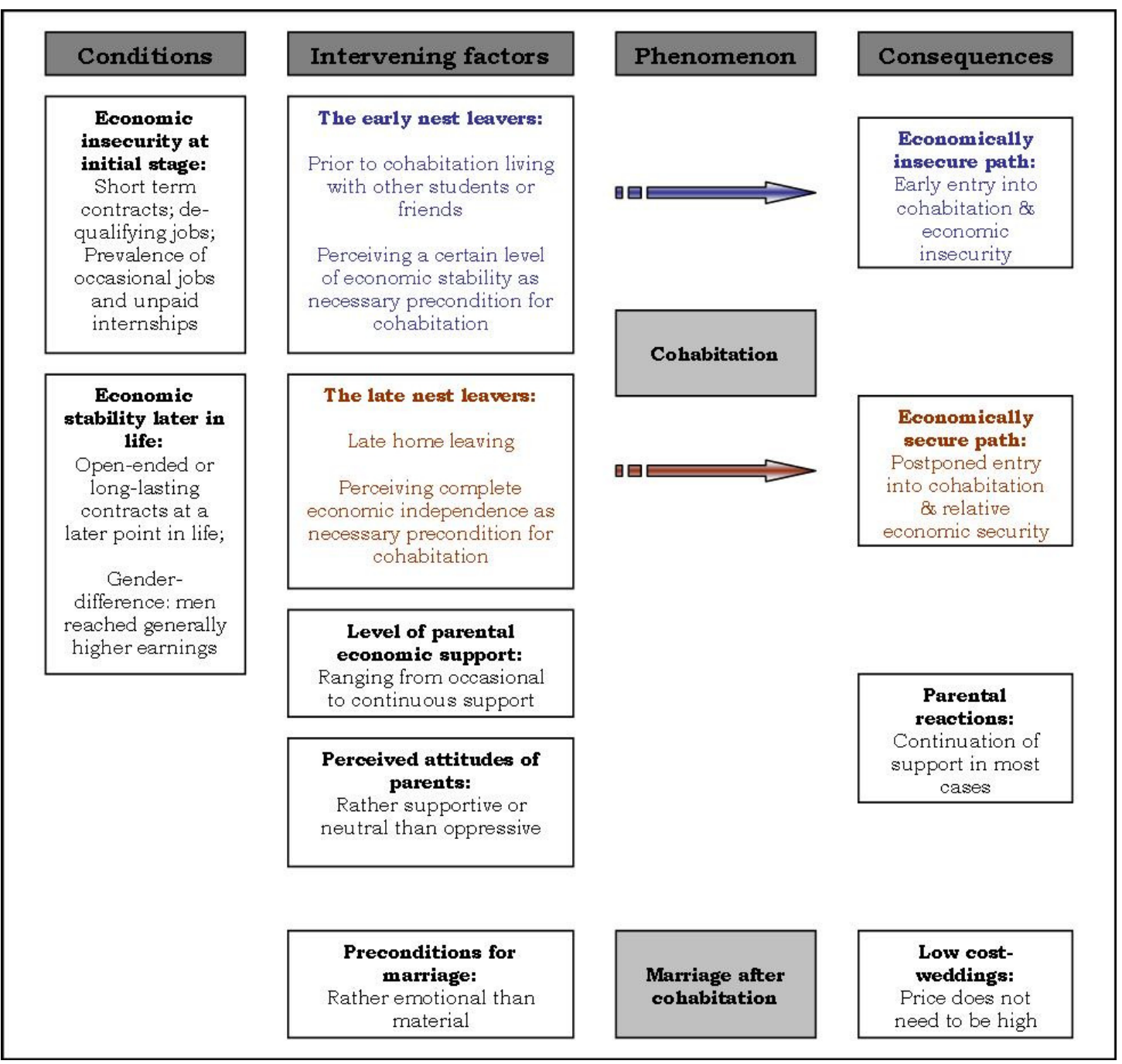

On average, women in the Bologna sample met their current partner at age 26.5 and entered cohabitation at age 28.6. The longest time between dating the partner and moving in together was four years. Given the occupational and consequently economic - difficulties, women in the Bologna sample acted in different ways to realize their desire of cohabitation. One group of women - exclusively those who came originally from Bologna - opted for an economically secure path. That meant they waited until they graduated from

\footnotetext{
${ }^{3}$ As shown in Table 1, 22 women in the Bologna sample had attained a university degree. On the other side, only 15 male partners held such a degree. Ten men had a higher secondary level of education, and three men had a lower secondary level of education.
} 
university, searched for and found an adequate job, and only then moved out of the parental home. Thus, their strategy was to wait until they reached a certain level of economic security before risking the major step of leaving home. Most of them then lived on their own or shared an apartment before deciding to cohabit, but they could only afford to follow this path if they were taking studies in their hometown. Eleonora (34), who was cohabiting, remembered the situation this way:

"I started work and when I saw that the job gave me some kind of guarantee that I was economically independent from my parents, I decided to start living in this flat."b

Further, women who chose the economically secure path stated recurrently that at least one income was necessary before deciding to cohabit. In addition, this income should be "secure," in the sense that the employment position should be more or less permanent. One woman said:

“One needs ... at least one secure job; I don't say two, but at least one among the couple. If not, it gets, let's say, a bit problematic, because already living with someone is an important step. If there is also a problem with work, that is, at least one of both needs to have a secure job."c

However, in general, men tended to have these more secure positions when entering cohabitation. And women often implicitly referred to their partners when emphasizing the importance of one secure income. Interviewees characterized their partner's employment position as followed:

"He has a - 'quote' - important job. I mean, it's not that it's more important than mine, but for sure he earns more and he is very busy ... more than I am."d

"From an economic perspective, he's more secure than I am; he has a higher salary than I have."e

Clearly, these interviewees attached great importance to having a certain level of economic security. Only when they had reached this level did they decide to leave home - and to enter cohabitation later on. As a consequence, both leaving the parental home and entering cohabitation were postponed until the precondition of economic stability was achieved.

A second group of women followed an economically insecure path, meaning that they left their parental home before having reached a certain level of 
economic security. All of them left home to continue their education and came to Bologna from outside the city. After their studies - seldom right in the middle - women moved in with their partner. At that point, they were still looking for an adequate employment position. Thus, when entering cohabitation they often suffered economic instability and uncertainty. Elena, aged 28 and cohabiting, left her parental home at age 24 . She said:

"Me and Paolo, we don't have secure jobs; so from an economic viewpoint, we always manage, but it's been a bit of a gamble. We are never sure that we earn that amount of money every month." ${ }^{\prime}$

Carlotta (26), who graduated from university about one year prior to the interview, faced huge problems in finding a job. At the time of the interview, Carlotta was working part-time for an educational institution, yet her income was not sufficient to rent a flat. Therefore, Carlotta was still sharing the apartment with other people and lived with her partner in a double room:

"It's not living with someone ... in the conventional sense. It is sharing a room in an apartment, because, mainly because of economic reasons. We could never share a flat on our own, only us (...) it's not possible at the moment because I don't earn enough (...) I don't have a lot of money. Once I pay the rent, I have very little to live on."g

Women who followed the economically insecure path had to confront a very high level of economic insecurity. The quotations from the interviews provide evidence of the remarkable effort these young adults had to put out when deciding to opt for an informal union.

Nevertheless, the fact that some women decided for an economically secure path, whereas others opted for an insecure path only partially supports the hypothesis of the higher compatibility of informal unions with the new demands of the labor market, such as flexibility, mobility, or insecurity. Women who opted for a secure path could rely on the fact that their family lived in the same town. Only when the preconditions for leaving home and cohabitation were given - namely economic independence - did these women choose that step. In many cases the interviewee's partners held secure employment contracts when the couple opted for cohabitation. This fact indicates a higher importance of the male's earnings as compared to the women's income. Further, women who opted for an economically insecure 
path were exclusively those who left their parental home prior to cohabitation in order to work or study in Bologna. To some extent, these women lived anyway in a financially insecure situation. Cohabitation did not downgrade their position, but allowed them to share both time and expenditures with their partner. In fact, the high number of temporary, though unstable jobs allowed them to be together before finding stable employment. Several couples did take advantage of the availability of temporary, unstable jobs to take on the risk of informal union formation. From that perspective, informal unions were indeed highly compatible with economic insecurity.

As to the transition from cohabitation to marriage, exclusively women coming from the southern regions of Italy pointed to the influence of economic factors. They referred, for instance, to high wedding costs as a reason for postponing marriage. Most women in Bologna, however, reported no additional economic conditions for marriage as compared to cohabitation. Instead, they mentioned ideational preconditions, such as the willingness to overcome common difficulties and achieve maturity. The women seldom opted for big celebrations when entering marriage. In Emilia-Romagna almost 50\% of weddings were in fact conducted at the registry office (ISTAT 2006) rather than in church. It seems that the economic preconditions to enter cohabitation were almost the same as for marriage. Thus, in the context of Bologna, marriage was not necessarily seen as an expensive choice. Women coming from southern regions pointed to the high costs of the wedding party and further preconditions of marriage, such as owning an apartment. However, the question that should be posed is this: Is cohabitation - in contrast to marriage - an expensive choice, as parents might withdraw from supporting their adult children? Interestingly, in Bologna, only a small group of interviewees had to fear a loss of financial support. The majority of women were supported by their families when deciding for and entering an informal union. Women reported for instance:

"As to that, however, they never tried to hinder me and from my point of view they respect me and hence I respect them."h

“... they always used to trust in my judgment, so if it was OK for me it was OK for them, too." $\mathrm{i}$ 
Consequently, most women could rely on parental support in situations of economic need (for more detailed results on parental reactions on cohabitation in both regional contexts, see Schröder 2007). Thus, in many cases, the preconditions for cohabitation and marriage were almost the same, ranging from a certain level of economic independence to having at least one secure income.

\section{2 "Prolonged Economic Insecurity" in Cagliari}

As we did for Bologna, we also developed a coding paradigm for Cagliari (see Figure 4). With regard to the economic conditions, we identified "prolonged economic insecurity" in Cagliari. Since the labor market situation tended to be worse in Sardinia and the South, interviewees in Cagliari encountered even more problems than the Bologna sample in finding an adequate employment position. Only a few women managed to find an open-ended position, although the majority of them still tried to locate contracts of this kind. In general, women did several jobs at the same time or had one shortterm contract after the other, sometimes interrupted by periods of unemployment.

Barbara, aged 32 and cohabiting, graduated from university at age 30. At the time of the interview, she had "no real employment" and "made various things." From time to time she assisted a professor, worked as a tutor, did internships, engaged in some cultural projects and similar short-term jobs:

"Thus, at the moment, after my studies, it happens that I collaborate with the professor who supervised my master's thesis. I do some translations, organize conferences, and so forth. I'm working as tutor for another professor as well. After my studies I did an internship here [at a cultural institute] and ... it was an institute, which I knew only by name, but I was very interested in it. (...) Besides I did various things. I participated in the political life in Cagliari, which was somehow important to me as it is a specific domain. Then, by accident I met people who did some voluntary service at the cinema and then I also volunteered there and learned to show movies, I organized cinema reviews, and so forth. This was an important experience, too. (...) I mean, my family even gives me some money. I have some money from the collaborations I did with the professor. Some more - but very little I got from the work as tutor. They actually approve 25 hours, that's 25 hours per semester (...) But there are a lot of projects and with my friends, those from the cinema, we hope to organize a festival in the summer and hope to have some funding. Thus, a little bit [of money] arrives. Also, with work, I do whatever comes up, translations and things like that." $j$ 
Most of the jobs Barbara engaged in were poorly paid, others not at all. Other interviewees complained that all positions were only fixed-term contracts. Viviana (36) even reported that women faced much more difficulty in finding a job in Cagliari than men did. As employers were afraid that married women might become parents soon, they preferred to hire unmarried women:

"The problem is the following: it is really difficult to find employment here in Sardinia and also here in Cagliari. Women who are married often don't have a chance. When I go to job interviews, they ask me whether I'm married, whether I have children or even whether I'm engaged. It's like: 'Let's see whether she will marry'." k

Figure 4: Coding Paradigm for the Cagliari interviews

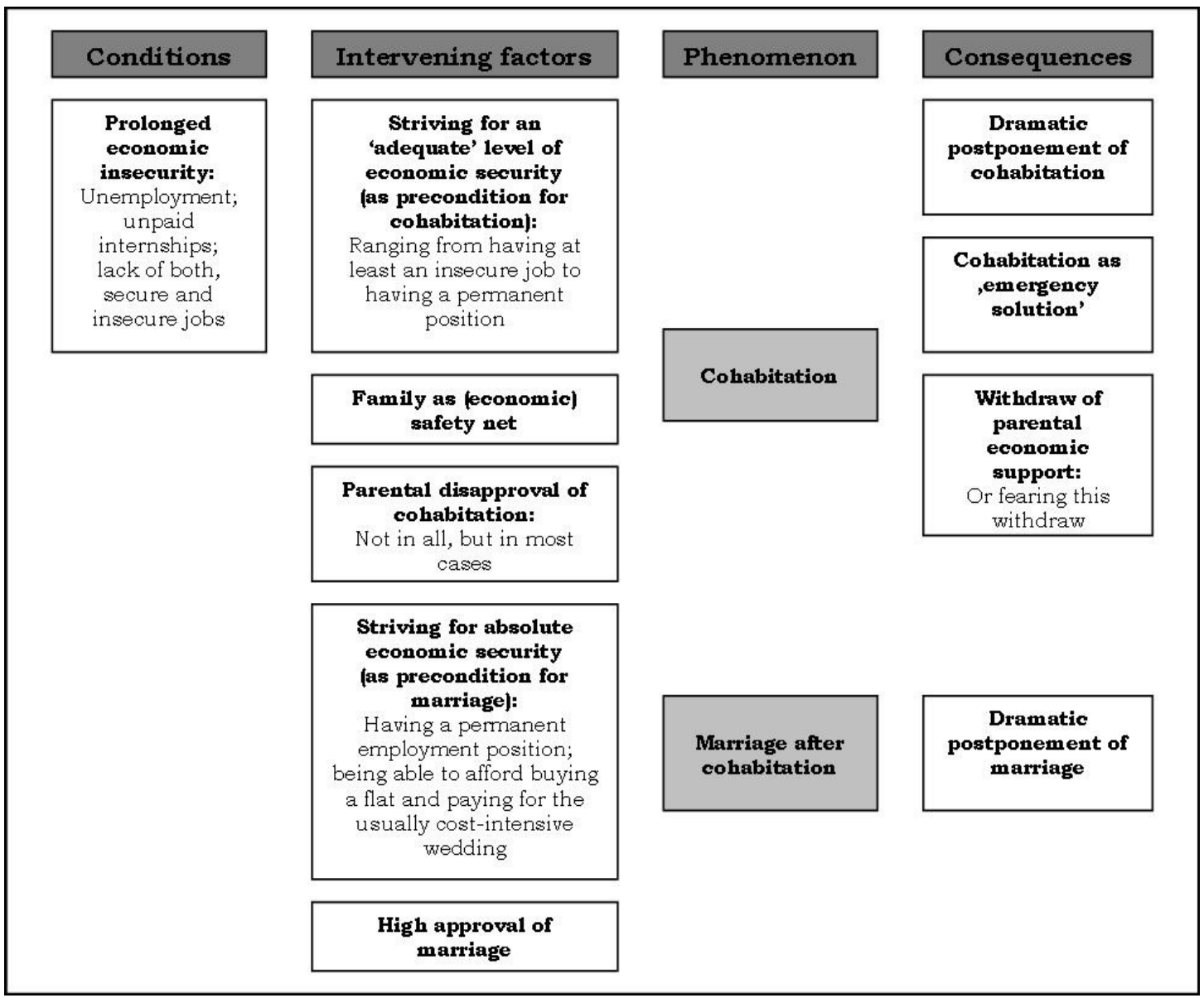

In fact, after having had several fixed-term contracts, at the time of the interview Viviana was unemployed. She was cohabiting and childless, but planned the wedding for the following year. Viviana felt under much pressure to find a more or less secure employment position before entering marriage; however, after having experienced the bad employment situation 
in Sardinia for almost sixteen years, she seemed to have given up hope. Other interviewees tried to counter employment insecurities by continuing to assert their qualifications. For example, during or after their studies, women completed internships, took private lessons, or went abroad in order to gain further knowledge. Despite these efforts, they had very little success when entering the labor market. Patrizia, aged 39 and cohabiting, reported this phase of her professional career:

"After my studies - I graduated in 1996 - I started to apply for jobs but didn't manage to find a steady job, let's call it like that, a job I can stay in for the rest of my life. I have some job experience in the sense that I worked in an assurance company for some time, [I earned] enough to pay the petrol for the car and these things and I didn't have much income (...) Later, in 1998, I started to work for the local authority and I am still working there but my contracts are renewed regularly, every year or so, every semester or so. Now I have a contract that ends in January 2007.”

Given her occupational prospects, it seems that the effort Patrizia invested in her training did not result in a corresponding outcome. The pattern applied to several of our interviewees. Although they engaged in several activities, they were seldom rewarded adequately.

As in Bologna, women in the Cagliari sample tended to have higher educational degrees than their partners; whereas 22 interviewees graduated from university, only about 16 male partners did so. ${ }^{4}$ Some men managed to have a secure employment position, working for instance as a researcher, teacher or in another white-collar job. However, most of them faced difficulties finding a job too. Some experienced the unexpected loss of a job; others had problems finding an open-ended contract. Alice, aged 32 and cohabiting, reported about the unfavorable payment practices her partner was exposed to:

"[He has] a fixed contract that gets renewed, I don't know, every six months or every year or so. But always for a fixed period. Also, the salary is not paid monthly. They pay only if the region pays the money he is paid from ... for example, September, October, November, December, and they pay him in January. Thus, in January he gets four salaries. Then he works in January, February, March, and April and they give him the money in May or June. This means that he needs to be well organized. He needs to be organized, if not he's not able to live on the money during the months he doesn't receive pay. All the contracts are like that. He only and really only works in this way."m

\footnotetext{
${ }^{4}$ However, among the male partners who finished university, five completed the doctorate. Among the Cagliari sample, eleven men reached higher secondary level of education and one man had a lower secondary level of education.
} 
As a consequence, some of the interviewed women were - at least temporarily - the main breadwinners within the couple or family. Under these circumstances, the importance of women's income increased.

Among the Cagliari sample, most interviewees stressed the impact of their individual labor market situation on their choice of cohabitation. Nicoletta (36), for instance, left her parental home at age 26. In order to cohabit, she and her partner went to Scandinavia. At that time the couple was still attending university and believed that they could afford to live together only there:

"Because it was possible there, and not here. Here it wouldn't have been possible. Impossible since the economic arrangements are different, they don't give you the chance to stand on your own feet. So we went there and we started working right away, we did both, we studied and we worked. Here it wouldn't have been possible. I think that my story is in some way emblematic of a situation that is almost universal here. Here you marry late and you miss out living with someone. Many do that because it gives them a lot of trouble to get the means necessary for this phase of transition where you decide what to do in life. You study, you risk having a job that is not the final one maybe ..."n

According to Nicoletta, it is the economic instability - caused by an unstable labor market and the lack of public support for young adults - that hampers the diffusion of informal unions in Italy. In her view, many more couples would prefer to move together if they had the financial means to do so. The interviews actually showed that most couples postponed entry into cohabitation until having reached an adequate level of economic security. This financial security, however, was always preceded by the highly timeconsuming graduation from university and the extensive search for a work position. The (partially dramatic) postponement of cohabitation is actually evident in the data, when observing the average age at union formation among the sample. On average, women met their current partner at the age of 26.5 years. However, they entered cohabitation on average at age 31.3. In eight cases, couples decided for an informal union only after 9 to 16 years of relationship. These couples were oriented to follow an economically secure path toward cohabitation. Two quotations serve to illustrate this path:

"We had to wait until we were able to pay the flat. We needed to have the money. I had to wait until I graduated from university, until I found a job. He first had one 
job, then he changed jobs, and we had to wait until he found a permanent position."o

"He also said that he preferred to have a situation economically stable enough not to have problems later, not to have worries. I don't say that now everything is fine, but we can pay the rent, the expenses, the cars. Before, we wouldn't have been able to." $\mathrm{p}$

In addition, we found that interviewees and their partners evaluated a male's earnings as more important when compared to the woman's, as can be seen from the first of the two quotes cited above. This not only accounts for cohabitation, but is also true for marriage. Patrizia (39) reported, for instance, that her partner abstains from proposing marriage to her, as he was unemployed and feared not to be able to take charge of her economically.

Whereas some couples opted for working toward a higher degree of economic security, other couples saw simply no way to realize cohabitation with the financial means at their disposal. These women emphasized that they had wanted to cohabit earlier, but that "their precarious job did not allow doing so." Though most couples sought for economic stability, the lack of both secure and insecure employment positions resulted in most cases in a situation of prolonged economic insecurity. During cohabitation, men and women recurrently lost their jobs and were constrained to search for new opportunities to re-enter the labor market. Under these conditions, many cohabiting couples chose to postpone marriage too. Katia (27), in fact, pointed out that she chose cohabitation and not marriage, as she had not the economic background to engage in a more serious kind of union:

"My choice was intuitive, I haven't thought a lot about it. A choice in the sense that I didn't have a fixed job, I worked on temporary work contracts, in a very precarious position ... so it was an intuitive choice as there was nothing certain at the economic level."q

Thus, in Cagliari economic uncertainty influenced union formation in two ways: Firstly, it delayed entry into cohabitation and provoked, secondly, a postponed transition from cohabitation to marriage. In the latter cases, cohabitation served as a kind of "emergency solution" until being able to afford a (usually expensive) wedding. As to the argument on higher compatibility of informal unions with the new demands of the labor market, we found split evidence: On the one side, the serious lack of stable and 
unstable employment made it impossible for several couples to opt for cohabitation. However, once an "adequate level of work and economic instability" was reached, cohabitation was more compatible with insecurity than marriage. Further, given the high costs associated with marriage (due to both a cost-intensive wedding and higher requirements linked to marriage), the decision for a conjugal union was highly expensive. Nonetheless, the interviews provided ample evidence that most couples in Cagliari strove for a conjugal union. Given the insecure labor market and the almost non-existence of government support for young adults, couples often had to rely on financial help from parents. However, several couples reported that parents withdrew support them when they decided to enter cohabitation. One interviewee related it this way:

"I bought everything, for instance the pots and all things of that kind. I bought everything. Because, not agreeing completely [with cohabitation], there was no such help."r

Therefore, in the context of Cagliari, the decision to cohabit was more often associated with high costs, given the lower financial help from parents. It was not surprising that several women accommodated their parents' wishes for traditional living arrangements such as marriage (see also Schröder 2007). In contrast to the Bologna sample, where the costs linked to formal and informal union formation were affordable and almost identical, the situation in Cagliari was quite different. In one way or the other, the cost of either cohabitation or marriage was perceived as incredibly high. Actually, it was seen as so high that couples considered themselves obliged to postpone cohabitation and marriage for a considerable time. The "collective" postponement of family formation has not only dramatic consequences for the couples themselves (for example, in terms of infertility), but also for the society as a whole.

\section{CONCLUSION}

Women among both the Bologna and Cagliari samples were hit by unemployment and a precarious labor market. However, the extent of employment instability varied to a considerable extent between the two cities. Women in Bologna experienced the lack of adequate occupational positions mainly at the initial stage of entry into the labor market. Women in 
Cagliari, by contrast, had severe problems finding a position throughout their professional life, in terms of both stable and unstable employment. Bearing in mind that almost all interviewees in both cities had high or very high levels of education, this observation is striking.

As the extent of labor market instability differed between the two regional contexts, it had a different effect on entry into cohabitation in Bologna and Cagliari. Women in Bologna followed in the main one of two different paths: One group opted to postpone cohabitation until a certain level of economic stability was reached; they entered their informal union rather late in life. A second group of women chose cohabitation while searching for an adequate occupation. These women and their partners entered informal union earlier; however, they more often suffered economic uncertainty at the beginning of their union. Although couples in Cagliari tended to postpone cohabitation too, almost all couples were exposed to financial difficulties resulting from unemployment and unstable jobs. The majority of interviewed women reported prolonged economic instability.

In both cases, in Bologna and in Cagliari, the labor market situation had an influence on the entry into first union. Quite a few women in Bologna tended to postpone union formation until graduating from university, finding a stable employment position and being able to afford buying their own apartment. In this respect, the (economic) barrier to enter a union was as high for informal unions as it was for formal ones. This pattern supports the findings of Billari et al. (2000), Schizzerotto and Lucchini (2002), and others who argue that in general postponement of any kind of union formation is caused by economic uncertainty. Further, as to economic support from parents, we found evidence that very few women had to fear economic sacrifices when entering cohabitation. The majority of women in Bologna could still rely on parental support in situations of need. In this respect, the costs for marriage and cohabitation were equally high and in general affordable for the women we interviewed, although in a very few cases cohabiting women reported very unfavorable economic conditions. In particular, women who came to Bologna in order to study could not rely on a local family security net. These women lived outside the parental home before finding an adequate employment position. As a consequence, they 
suffered economic instability. Their higher amount of flexibility (due to having already left their parental home) was indeed more compatible with new kinds of living arrangements, as assumed in the theory and hypotheses section of this paper.

In Cagliari, we observed two types of influence the labor market had on the women we interviewed. Firstly, the majority of couples had to postpone entry into their first union as they could not afford to pay the rent for a common apartment. Couples in Cagliari, in general, postponed their transition to an informal union to a much stronger extent than couples in Bologna did. Women in the sample decided to enter cohabitation on average at age 31 , whereas women in Bologna did so between age 28 and 29. This observation actually contradicts the "compatibility assumption". On the other hand, our data provide evidence that several couples opted for cohabitation as an "emergency solution". The high esteem for a marriage relationship which we found in Cagliari leads to the assumption that many couples would rather opt for marriage than for cohabitation as their first union. As a stable employment was seen as precondition for marriage, couples postponed the wedding. In this respect, labor market uncertainty deterred couples from taking the risk to make the transition from cohabitation to marriage. Though women showed rather conventional attitudes towards union formation, they opted for the new kind of living arrangement - which, in the end, gives at least some support to the compatibility argument. In addition, in the context of Cagliari, we found that both cohabitation and marriage were perceived as very expensive and, at least partially, unaffordable choices. As to cohabitation, it was seen as cost-intensive since parents might withdraw further economic support. Marriage, on the other hand, was perceived as expensive as well, since it was associated, for example, with a high-priced wedding. The situation in Cagliari made both choices so expensive that couples tended to postpone entry into either cohabitation or marriage - a choice which in the long run has severe consequences for the society as a whole.

Our study provides evidence for the different way couples in both regional contexts dealt with economic insecurity once they desired to live together. In Bologna, factors such as the availability of jobs (though insecure) and the 
stronger readiness of parents to support their children when cohabiting favored the relatively high diffusion of informal unions in the city. In Cagliari, by contrast, the spread of cohabitation was strongly hampered by precarious living conditions caused by a very high level of job insecurity and the absence of parental support to cohabiting couples. The economic conditions of both settings thus accounted to a large extent (though not exclusively) for the different development of cohabitation in the two regions.

\section{ACKNOWLEDGEMENT}

For their useful advice and suggestions I am grateful to Laura Bernardi and the members of the Independent Research Group "The Culture of Reproduction" at the MPIDR. For language editing I thank David Harrison and Susann Backer.

\section{LITERATURE}

ARNSTEIN, AASSVE, BILLARI, FRANCESCO C., and ONGARO, FAUSTA. 2000. The impact of income and employment status on leaving home: evidence from the Italian ECHP sample. MPIDR Working Paper WP 2000-012.

BARBAGLI, MARZIO, and SARACENO, CHIARA. 1997. Lo stato delle famiglie in Italia. Bologna: Il Mulino.

BECKER, GARY S. 1981. A treatise on the family. Cambridge, MA: Harvard University Press.

BECKER, SASCHA O., BENTOLILA, SAMUEL, FERNANDES, ANA, and ICHINO, ANDREA. 2005. Youth Unemployment and Perceived Job Insecurity of Parents and Children. IZA Discussion Paper No. 1836.

BERNARDI, FABRIZIO, and NAZIO, TIZIANA. 2005. "Globalization and the transition to adulthood in Italy," in Globalization, Uncertainty and Youth in Society. Edited by H.-P. Blossfeld, E. Klijzing, M. Mills, and K. Kurz, pp. 349-74. Routledge.

BERNARDI, LAURA, KLÄRNER, ANDREAS, and VON DER LIPPE, HOLGER. 2007. Job Insecurity and the Timing of Parenthood: A Comparison between Eastern and Western Germany. European Journal of Population (online publication).

BILLARI, FRANCESCO C. 2004. Becoming an Adult in Europe: A Macro(/Micro)Demographic Perspective. Demographic Research Special Collection 3: www.demographic-research.org.

BILLARI, FRANCESCO C., CASTIGLIONI, MARIA, CASTRO MARTIN, TERESA, MICHIELIN, FRANCESCA, and ONGARO, FAUSTA. 2000. Household and Union Formation in a Mediterranean Fashion: Italy and Spain. FFS Flagship Conference, Brussels, 29-31 May 2000. 
BILLARI, FRANCESCO C., PHILIPOV, DIMITER, and BAIZÁN, PAU. 2001. Leaving Home in Europe: The Experience of Cohorts Born Around 1960. International Journal of Population Geography 7: 339-56.

BILLARI, FRANCESCO C., and ROSINA, ALESSANDRO. 2003. Aiutare i giovani a diventare adulti. Quali le conseguenze sulla fecondità? Convegno "La bassa fecondità tra costrizioni economiche e cambio di valori", Accademia Nazionale dei Lincei, 15-16 May 2003 .

BRÜTTING, RICHARD. 1997. Italien-Lexikon. Berlin: Erich Schmidt Verlag GmbH \& Co.

BUBBICO, DAVIDE. 2005. Da sud a nord: i nuovi flussi migratori interni. Milano: Franco Angeli.

CHERLIN, A. 1992. Marriage, divorce, remarriage. Cambridge: Harvard University Press.

CLARKBERG, MARIN. 1999. The Price of Partnering: The Role of Economic WellBeing in Youth Adults' First Union Experiences. Social Forces 77: 945-68.

CORBIN, JULIET, and STRAUSS, ANSELM. 1990. Grounded Theory Research: Procedures, Canons, and Evaluative Criteria. Qualitative Sociology 13: 3-21.

DI GIULIO, PAOLA, and ROSINA, ALESSANDRO. 2007. Intergenerational family ties and the diffusion of cohabitation in Italy. Demographic Research 16: 441-68.

DIETRICH, HANS. 2002. "Jugendarbeitslosigkeit und Aktiver Arbeitsmarkt für Jugendliche in ausgewählten Europäischen Staaten. Entstaatlichung oder neue Verstaatlichung von Stratifikationssystemen," in Entstaatlichung und soziale Sicherheit: Verhandlungen des 31. Kongresses der Deutschen Gesellschaft für Soziologie in Leipzig 2002. Edited by J. Allmendinger, Opladen: Leske und Budrich.

DOLADO, J. J., FELGUEROSO, F., and JIMENO, J. F. 2000. Youth labour markets in Spain: Education, training and crowding-out. European Economic Review 44: 94356.

ERICKSON, BONNIE H. 1979. Some Problems of Inference from Chain Data. Sociological Methodology 10: 276-302.

FERRERA, MAURIZIO. 1996. The Southern Model of Welfare in Social Europe. Journal of European Social Policy 6: 179-89.

FLICK, UWE. 2002. Qualitative Forschung. Eine Einführung. Reinbek bei Hamburg: Rowohlt.

FONDAZIONE GIACOMO BRODOLINI. 2007. Job Instability and Family Trends. Rome, Italy: Fondazione Giacomo Brodolini.

GLASER, BARNEY G., and STRAUSS, ANSELM L. 1974. The Discovery of Grounded Theory. Strategies for Qualitative Research. Chicago: Aldine.

GOODMAN, LEO A. 1961. Snowball Sampling. The Annals of Mathematical Statistics 32: $148-70$.

GRILLO, FRANCESCA, and PINNELLI, ANTONELLA. 1999. "Sistema di genere e comportamenti coniugali e riproduttivi in Italia," in Nuzialità e fecondità in transformazione: percorsi e fattori del cambiamento. Edited by P. De Sandre, A. Pinnelli, and A. Santini, Bologna : Il Mulino. 
GRUPPO DI COORDINAMENTO PER LA DEMOGRAFIA. 2007. Rapporto sulla popolazione. L'Italia all'inizio del XXI secolo. Bologna: Il Mulino.

HOLDSWORTH, CLARE, and IRAZOBUI SOLDA, MARIANNA. 2002. First Housing Moves in Spain: An Analysis of Leaving Home and First Housing Acquisition. European Journal of Population 18: 1-19.

HURRELMANN, K. 2003. Der entstrukturierte Lebenslauf. Die Auswirkungen der Expansion der Jugendphase. Zeitschrift für Soziologie der Erziehung und Sozialisation 23: 115-26.

ISTAT. 2001. Census (Censimento) 2001 (www.istat.it).

ISTAT. 2006. Annuario Statistico Italiano (www.istat.it).

KIERNAN, K. 1999. Cohabitation in Western Europe. Population Trends 96: 25-32.

KIERNAN, K. 2004. "Unmarried cohabitation and parenthood: here to stay? European perspectives," in The future of the family. Edited by D. P. Moynihan, T. Smeeding, and L. Rainwater, New York: Russell Sage Foundation.

KOHLER, HANS-PETER, BILLARI, FRANCESCO C., and ORTEGA, JOSE A. 2002. The Emergence of Lowest-Low Fertility in Europe during the 1990s. Population and Development Review 28: 641-80.

LEWIS, SUZAN, SMITHSON, JANET, and BRANNEN, JULIA. 1999. Young Europeans' Orientations to Families and Work. Annals of the American Academy of Political and Social Science 562: 83-97.

MILLS, M., and BLOSSFELD, H.-P. 2005. "Increasing uncertainty and changes in the transition to adulthood in modern societies," in Globalization, uncertainty and youth in society. Edited by H.-P. Blossfeld, pp. 1-24. London: Routledge.

MULDER, CLARA H., and MANTING, DORIEN. 1994. Strategies of Nest-Leavers: 'Settling down' versus Flexibility. European Sociological Review 10: 155-72.

OPPENHEIMER, VALERIE K. 1988. A Theory of Marriage Timing. The American Journal of Sociology 94: 563-91.

OPPENHEIMER, VALERIE K. 1997. Women's employment and the gain to marriage: The specialization and trading model. Annual Review of Sociology 23: 431-53.

OPPENHEIMER, VALERIE K. 1994. Women's Rising Employment and the Future of the Family in Industrial Societies. Population and Development Review 20: 293-342.

PISATI, MAURIZIO, and SCHIZZEROTTO, ANTONIO. 2003. Mid-career women in contemporary Italy. Globalife Working Paper No. 57.

REHER, DAVID. 1998. Family Ties in Western Europe: Persistent Contrasts. Population and Development Review 24: 203-34.

ROSINA, ALESSANDRO, and FRABONI, ROMINA. 2004. Is marriage losing its centrality in Italy? Demographic Research 11.

ROSSI, GIOVANNA. 1997. The nestlings. Why Young Adults Stay at Home Longer: The Italian Case. Journal of Family Issues 18: 627-44.

SABBADINI, LINDA L. 1997. "Le convivenze "more uxorio," in Lo stato delle famiglie in Italia. Edited by M. Barbagli and C. Saraceno, Bologna: Il Mulino. 
SARACENO, CHIARA. 1994. The Ambivalent Familism of the Italian Welfare State. Social Politics 1: 60-82.

SCHIZZEROTTO, ANTONIO, and LUCCHINI, MARIO. 2002. "La formazione di nuove famiglie in Italia e Gran Bretagna: un'analisi longitudinale," in Famiglie: mutamenti $e$ politiche sociali, Vol. 1. Edited by Osservatorio nazionale sulle famiglie e le politiche locali di sostegno alle responsabilità familiari, Bologna: Il Mulino.

SCHRÖDER, CHRISTIN. 2006. Cohabitation in Italy: Do Parents Matter. GENUS LXII: 53-85.

SCHRÖDER, CHRISTIN. 2007. The influence of parents on cohabitation in Italy insights from two regional contexts. MPIDR Working Paper WP 2007-030.

SGRITTA, GIOVANNI B. 2002. "La transizione all'età adulta: la sindroma del ritardo," in Famiglie: mutamenti e politiche sociali. Edited by Osservatorio nazionale sulle famiglie e le politiche locali di sostegna alle responsabilità familiari, Bologna: Il Mulino.

SIMÓ NOGUERO, CARLES, CASTRO MARTÍN, TERESA, and SORO BONMATÍ, ASUNCIÓN. 2005. "The Spanish case. The effects of the globalization process on the transition to adulthood," in Globalization, Uncertainty and Youth in Society. Edited by H.-P. Blossfeld, E. Klijzing, M. Mills, and K. Kurz, pp. 375-402. Routledge.

SMOCK, PAMELA J., and MANNING, WENDY D. 1997. Cohabiting Partners' Economic Circumstances and Marriage. Demography 34: 331-41.

WHITE, LYNN, and ROGERS, STACY J. 2000. Economic Circumstances and Family Outcomes: A Review of the 1990s. Journal of Marriage and the Family 62: 1035-51.

WILSON, W. J. 1996. When work disappears: The world of the new urban poor. New York: Vintage Books.

\footnotetext{
a "Prima facevo delle supplenze nella scuola elementare oltre ho ancora fatto i lavori più svariati tra cui ho fatto l'attrice per un periodo o ho lavorato come aiuto cucina nei ristoranti così d'estate, ho lavorato per diversi anni con gli adolescenti a rischio."

b "Avevo iniziato a lavorare e dopo che ho visto che il lavoro mi dava una certa garanzia del fatto che ero indipendente dai miei genitori per vivere, economicamente a quel punto ho deciso di venire a vivere in questa casa."

c "Ci vuole ... il lavoro fisso almeno uno dei due, non dico tutti e due, ma almeno uno dei due perché se no diventa diciamo un po' problematico perché già la convivenza è un passaggio importante se poi hai anche il problema del lavoro, almeno uno dei due deve avere un lavoro fisso...ecco."

d "Lui fa un lavoro tra virgolette importante, cioè non che sia più importante del mio però sicuramente guadagna di più ed è molto impegnato...più di me.”

e "Lui è economicamente più solido di me, ha uno stipendio più alto del mio."

f "Io e Paolo non abbiamo dei lavori sicuri e quindi a livello economico ce l'abbiamo sempre fatta ma era un po' una scommessa, non abbiamo mai la sicurezza che tutti i mesi noi guadagneremo questo."
} 
g "Non è una convivenza ... in senso stretto, è una condivisione di una stanza all'interno di un appartamento perché soprattutto perché per ragioni economiche non potremmo mai condividere solamente una casa, una casa da soli (...) comunque è impossibile al momento perché io non ho abbastanza reddito (...) io ho pochi soldi quindi, una volta che do i soldi dell'affitto mi rimane molto poco."

h "Però non hanno mai cercato da questo punto di vista di ostacolarmi e questo secondo me è una forma di rispetto nei miei confronti e di riguardo io rispetto loro."

i " ... hanno sempre avuto abbastanza fiducia sul mio giudizio per cui se andava bene a me, andava bene anche a loro.”

j "E quindi adesso dopo la laurea mi capita di fare delle collaborazioni per la professoressa con la quale ho fatto la tesi all'università, traduzione, organizzazione di convegni e così...poi sto facendo anche un tutorato per un'altra professoressa. Dopo la laurea ho fatto il tirocinio qua [un'istituto di cultura] e ... che era un centro che io conoscevo solamente per nome e però mi interessava molto (...) Poi ho fatto anche svariate cose partecipando diciamo un po' partecipando alla vita politica cagliaritana e quindi questo va beh ha significato molto per me perché si tratta di un'area un po' particolare e poi...così per...per pura casualità ho conosciuto delle persone che facevano volontariato in un cinema d'esse e ho fatto volontariato à e imparato a proiettare le pellicole, ho organizzato rassegne cinematografiche e così e anche quella lì è stata un'esperienza importante (...) No, allora ...in realtà un po' di soldi me li danno i miei, un po' di soldi li ho dalle collaborazioni che faccio con la professoressa della tesi, qualcosa che è molto poco dal lavoro di tutorato ... perchè comunque riconoscono 25 ore, riconoscono 25 ore per ogni semestre (...) Però ci sono molti progetti e adesso con questi altri amici, con i quali è il mio gruppo di cinema, speriamo di riuscire ad organizzare un festival in estate con un finanziamento quindi comunque qualcosina arriva. Poi, insomma come lavori faccio anche quello che mi capita, traduzioni o cose del genere."

k "Il problema è questo, qua in Sardegna trovare lavoro è veramente difficile e anche qui a Cagliari. Il curriculum di una donna sposata non viene preso in considerazione. Quando vado a fare i colloqui mi chiedono se sono sposata, se ho figli e addirittura se sono fidanzata cioè del tipo 'Sentiamo un po' se questa si deve sposare"."

1 "Dopo la laurea, mi sono laureata nel '96, ho iniziato a presentare curriculum però non sono riuscita a trovare un lavoro duraturo diciamo così, a tempo indeterminato. Ho avuto delle esperienze lavorative nel senso che ho lavorato in una compagnia di assicurazioni per un periodo, giusto per pagarmi la benzina per la macchina e queste cose così e non avevo gran che entrate (...) Poi nel '98 ho iniziato a lavorare per il comune e da lì sto lavorando da tempo con pratiche con contratti rinnovabili di volta in volta, annuali, semestrali e adesso ho un contratto che mi scade a gennaio del 2007."

$\mathrm{m}$ "[Lui ha un contratto] a tempo determinato e viene rinnovato non so se di sei mesi in sei mesi o di anno in anno. Comunque tutto a tempo determinato. Tra l'altro la retribuzione non ha una cadenza mensile, ma viene pagato sol quando la Regione stanzia questi contributi per cui lui lavora ... per esempio Settembre, Ottobre, Novembre, Dicembre e i soldi glieli danno a Gennaio. Per cui a Gennaio avrà quattro retribuzioni. Poi lavorerà Gennaio, Febbraio, Marzo e Aprile e i soldi glieli danno a Maggio o a Giugno. Quindi lui deve essere ben organizzato. Deve essere organizzato altrimenti non riesce poi a vivere nei mesi in cui non percepisce lo stipendio. Tutti i contratti sono così. Lui lavora solo ed esclusivamente in questo modo." 
$\mathrm{n}$ "Perché era possibile lì e non qua. Qui sarebbe stato impossibile. Impossibile perché il tessuto economico è un altro, non ti dà l'opportunità di vivere sulle tue gambe così noi siamo andati là e abbiamo cominciato a lavorare subito, a studiare $\mathrm{e}$ a lavorare insieme. Qui sarebbe stato impossibile. Guindi penso che quello ... che la mia storia sia in qualche modo emblematica di una situazione che qui è generalizzata, per cui ci si sposa tardi e si salta il passaggio della convivenza che molti farebbero proprio perché si stenta ad avere i mezzi per vivere insieme e a vivere quella fase transitoria in cui si decide cosa si farà nella vita. Si finiscono gli studi, rischi di fare un lavoro che magari non sarà quello definitivo ...”

o "Dovevamo aspettare di poterci pagare una casa. Dovevamo avere la possibilità. Ho dovuto aspettare di laurearmi, di trovare un lavoro, lui prima faceva un lavoro poi l'ha cambiato e dovevamo aspettare che lui trovasse un lavoro sicuro."

$\mathrm{p}$ "Anche lui ha detto che preferiva avere una situazione economica stabile per non avere problemi poi, per non dover avere preoccupazioni. Non dico che adesso vada benissimo, però possiamo pagare l'affitto, le spese, le macchine. Prima non l'avremo potuto fare."

q "La mia scelta è stata una scelta istintiva, poco pensata. Una scelta nel senso che comunque non avendo un lavoro fisso io, ma lavorando con contratti a termine, con un lavoro molto precario ... cioè comunque è una scelta istintiva perché non c'era niente di sicuro a livello economico.

$\mathrm{r}$ "Ho comprato tutto io, tipo le pentole e tutte queste cose qua. Ho comprato tutto io. No, perché comunque non essendo completamente d'accordo non c'è stato questo aiuto." 